\title{
Survival Three Decades after Cabrol-Operation for Aortic Aneurysm in Marfan-Syndrome
} \author{
Massberg ${ }^{3}$, Rhoia Neidenbach ${ }^{1}$ and Harald Kaemmerer ${ }^{1 *}$ \\ ${ }^{1}$ Department of Pediatric Cardiology and Congenital Heart Disease, Deutsches Herzzentrum München, Germany \\ ${ }^{2}$ Division of Radiology and Nuclear Medicine, Technische Universität München, Germany \\ ${ }^{3}$ Department of Cardiovascular Diseases, Technische Universität München, Germany
}

Claudia Pujol Salvador ${ }^{1}$, Siegrun Mebus ${ }^{1}$, Albrecht Will ${ }^{2}$, Stefan Martinoff ${ }^{2}$, Christian Meierhofer ${ }^{1}$, Steffen

Submission: February 20, 2017; Published: May 03, 2017

*Corresponding author: Harald Kaemmerer, Deutsches Herzzentrum München, Department of Paediatric Cardiology and Congenital Heart Disease, Lazarettstrasse 36, 80636 München, Germany, Fax: +49-89-1218-3013; Tel: +49-89-1218-3011; Email: Kaemmerer@dhm.mhn.de

\section{Case Report}

A 68-year-old woman with Marfan syndrome presented to our outpatient clinic. In 1984 a huge aortic root aneurysm and severe aortic valve regurgitation were diagnosed. She underwent Cabrol-type aortic root and aortic valve replacement with $31 \mathrm{~mm}$ Björk-Shiley prosthesis. Only paroxysmal atrial fibrillation was reported since surgery. She was under therapy with beta-blocker, ACE inhibitor, diuretic and oral anticoagulation.

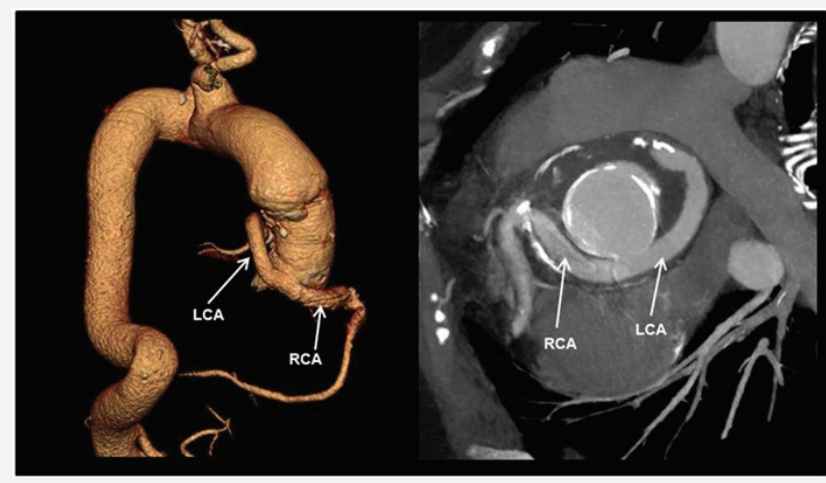

Figure 1: Multislice CT with depiction of the left (LCA) and right (RCA) coronary arteries.

The echocardiography revealed normal aortic valve function and flow through the aortic root and arch. There was only a mild mitral regurgitation. In order to safely exclude relevant changes in the area of previous surgery in the ascending aorta, at the bypass and in the coronary arteries, Multislice Computer Tomography imaging (MS-CT) was performed. MS-CT depicted non-significant atheromatous plaques in the coronary interposing tube graft and an ectasia of the ascending aorta at the distal anastomosis of the graft (Figure 1).

\section{Discussion}

Cabrol-technique for aortic root and valve replacement was first described by Cabrol et al. [1] for the treatment of aneurysms of the ascending aorta, being mainly employed when the tissue at the coronary ostia was very fragile or coronary arteries were torn or tensed rendering re-implantation impossible [1,2].

During the Cabrol operation the ascending aorta is replaced by a valved Dacron conduit. A separate Dacron interposition tube graft is inserted, connecting the left and right coronary ostia. This Dacron graft, is then anastomosed side-to-side to the aortic conduit [1]. In the past decades, several modifications have been introduced to the original version of the Cabrol approach.

Cabrol-operation was considered to offer a safe and tension-free anastomosis when conventional re-implantation techniques did not allow to connect the coronary arteries and the aortic conduit [1,2]. Initially, Cabrol-procedure was demonstrated to be associated with a 30 -day mortality of $9 \%$ or less. Long-term survival rates of $48-76 \%$ during the first decade [2], and of approximately $60 \%$ at 16 years have been reported [3]. Early mortality was higher in the first surgeryseries, probably related to a lower degree of experience.

Most common late complications were aortic dissection and late coronary artery stenosis. Age, Marfan syndrome, cross-clamp time and cardiopulmonary bypass duration were significant independent risk predictors for late mortality 
[3]. The non-negligible coronary complications [4] and the emergence of the "button" technique have reduced Cabrol indications. Cabrol-operation is currently applied as first-line procedure only in some selected cases, or as a rescue operation for complex aortic disease [2].

\section{Conclusion}

The patient presented here is a unique and an excellent result after Cabrol-Operation despite the presence of Marfan syndrome. To our knowledge, there are no data on the outcome of patients undergoing the Cabrol approach beyond 20 years after surgery.

This work is licensed under Creative Commons Attribution 4.0 License DOI: 10.19080/JOCCT.2017.05.555653

\section{References}

1. Cabrol C, Gandjbakhch I, Cham B (1978) Aneurysms of the ascending aorta; total replacement with reimplantation of the coronary arteries. Nouv Presse méd 7(5): 363-365.

2. Kourliouros A, Soni M, Rasoli S, Grapsa J, Nihoyannopoulos P, et al. (2011) Evolution and current applications of the Cabrol procedure and its modifications. Ann Thorac Surg 91(5): 1636-1641.

3. Gelsomino S, Frassani R, Da Col P, Morocutti G, Masullo G, et al. (2003) A long term experience with the Cabrol root replacement technique for the management of ascending aortic aneurisms and dissections. Ann Thorac Surg 75(1): 126-131.

4. Kitamura T, Kigawa I, Fukuda S, Miyairi T, Takamoto S (2011) LongTerm results with the Cabrol aortic root replacement. Int Heart J 52(4) 229-232.

\section{Your next submission with Juniper Publishers will reach you the below assets}

- Quality Editorial service

- Swift Peer Review

- Reprints availability

- E-prints Service

- Manuscript Podcast for convenient understanding

- Global attainment for your research

- Manuscript accessibility in different formats ( Pdf, E-pub, Full Text, Audio)

- Unceasing customer service

Track the below URL for one-step submission https://juniperpublishers.com/online-submission.php 